\title{
A Male Transformation into a Female Character on the Noh Stage
}

\author{
Violetta BRAZHNIKOVA TSYBIZOVA*
}

\begin{abstract}
Femininity and the feminine figure itself in Noh theatre plays an important role, though nowadays the interpreter is fundamentally masculine. The central aim of impersonating feminine roles by masculine performers, and therefore creating the masculine femininity consists of transmitting the spirit and the state of mind in place of ordinary copies of external femininity signs. That is the basis of the work of interpretation of the actor in the Noh theatre, similar in the case of both male and female roles. However, this paper will examine the technique in both occasions, and the difference in the event that there is a difference.
\end{abstract}

Keywords: Noh stage, impersonating, masculine femininity, feminine figure, Zeami

\section{Izvleček}

Ženskost in ženske figure same po sebi imajo v gledališču $n o \bar{o}$ pomembno vlogo, čeprav so danes izvajalci v osnovi moški. Osnovni cilj poosebljanja ženskih vlog moških izvajalcev in tako ustvarjanja moške ženskosti je sestavljen iz prenašanja duha in stanja miselnosti na mesto navadne kopije zunanjih znakov ženskosti. To je temelj dela interpretacije igralca $\mathrm{v}$ gledališču $n \bar{o}$, ki je podobno v primeru tako moških in ženskih vlog. Ta članek bo tako preučil tehinke v obeh primerih in razlike, v primeru, da se pojavljajo.

Ključne besede: gledališče $n \bar{o}$, moška ženskost, ženske figure, Zeami

\footnotetext{
*Violetta BRAZHNIKOVA TSYBIZOVA, PhD, Research Associate, Waseda University, Tokyo, Japan.

b.sumire[at]gmail.com
} 


\section{Introduction}

The feminine figure holds a significant place in the Noh theatre, being one of the five Noh play categories dedicated entirely to women. In a great number of plays the main character is the feminine one, with a wide spectrum of ages, emotions, social statuses and principal purposes of the roles for the protagonist. Unlike Kabuki, where the male interpreter tries to imitate women, Noh offers a radically different approach, using the same interpretative technique for both masculine and feminine roles. Actually, not to imitate, but to transmit the spirit, and not to copy, but to capture the state of mind is the basis of the interpretation by the actor in the Noh theatre. In Noh theatre, it is more of an aesthetic than psychological procedure. ("Algunos Shite típicos...”)

According to the Noh system, the primary objective of performance consists of transmitting the feminine spirit, through the tight control of energy that the actor uses according to each role, and with the total avoidance of the naturalist procedure. The femininity in Noh is transmitted through external tangible signs such as the mask, wig, and costume, and supported by the signs of a different nature as the rhythm and the energy of the movement. Although contemporary theory has already made a great incursion in the Noh dramatic literature, the internal process of the interpreter, the reasons, and the results of the masculine attempt to temporarily become a woman on the Noh stage remain insufficiently studied. This paper focuses on how the actor adopts the feminine spirit without losing his masculine essence, and will highlight the procedures of this unique method based on the intellectual agreement with the public.

On the other hand, it must be noted that the whole study refers to Noh theatre, and in no case will analyze Nohgaku, which is the compilation of Noh and Kyōgen.

\section{Masculinity and Femininity in Japanese Society}

Obviously, the concept of femininity was altering over time according to social reforms and changes. The ideal submissive woman of the Edo period (1603-1868) differs in a great manner from the Noh characters mainly composed following the aesthetic standards of femininity in the Heian (794-1159) or Muromachi (13371573) period. The capricious Ono-no Komachi from Kayoi Komachi, the jealous Rokujō-no Miyasudokoro from Aoi no Ue, and the dancer girl from Dōjōji, terrible in her passion, do not show any sign of submission to the terrestrial man. Only 
praying and the fear of the spiritual and physical punishment in hell can reduce them. On the other hand, submission is also present through the characters' behaviour, as one of the signs of the ultimate femininity even in these ancient times. For instance, Yuya, from the play of the same title, is a supreme example of the obedient and delicate woman. Whereupon, even changing the femininity signs over time, the main one is the obedience and submission to the male predominating force to some extent to the present day. According to Hofstede's research $(1980,288)$, modern Japanese society is still associated with the dominant masculine factor and the massive feminine submission as main aspects of traditional gender role ideology. However, the $20^{\text {th }}$ century had introduced in the masculine/feminine relationship such innovations as laws that should regulate their correlation in both the domestic and professional sphere, though the following study will highlight to what extent these laws are used in practice.

The concept of "masculinity and femininity" within the context of this article means mainly the handling of tolerance/intolerance. Throughout the history of world culture it can refer to religious and/or territorial causes, causes of sex (opposition woman/man), etc. However, it almost always insinuates to be inside or to be outside some established system, in other words to be able to represent the other, or of being represented by the other. Also, the one that is outside the system is the "other", or the weak one. Hierarchies arise as a result of the recognition of differences, creating the exclusion of the "other" and nostalgia of the one where this one is free to decide the fate of others. This confrontation can be expressed by different words in a variety of contexts:

body/soul

irrational/rational

matter/form

male/female, etc.

The confrontation of the last two polarities is still a pending subject even in the Western world, which fails to overcome a significant amount of prejudice that emphasizes male superiority in society, and has become increasingly alarming in the world inevitably referred to as "Oriental". This fact cannot be omitted entirely as a decisive impact on the development of the so-called traditional Japanese theatre where the main performer even nowadays is still the male one. Though currently Noh theatre admits the creation of the feminine troupes, it should not be 
forgotten that the value of such performances is considered quite low among the Japanese Noh researchers. On the other hand, Kabuki theatre suffers from the official government ban on female presence from 1629, and still no actress is on the Kabuki professional stage, though the Meiji government (1868-1912) had removed the ban two hundred and fifty years later. Traditionally, the Japanese woman lived behind closed doors during the eight centuries of military rule, and is seen as the negative, the passive, the weak, and the submissive member of the society, corresponding to her role of yin in the Chinese duality system of the world. Femininity in the Middle Age is associated with the jealousy too, and therefore even nowadays the traditional feminine wedding costume includes tsunokakushi 角隠 L (“a piece of fabric that hides the horns any woman is supposed to have"). Abandoning her ego by the act of the wedding, the woman agrees to be an obedient wife. Thus, obedience, passiveness, and jealousy are the main signs of traditional Japanese femininity, widely represented on the Noh stage, though this image largely differs from the image of the modern Japanese woman. Therefore, while Edo period shows some important changes in the image of women, at least on Kabuki stage and on the social stage of Japanese society, even more can be expected from the contemporary times. Usually, in the old days a woman dedicated her entire life to ie 家 ("the family/home"), meanwhile the man, whose role is strong, active and bright in accordance with yang, lived for the state. The male function within the family is similar to the one that shogun holds towards the state. In other words, shōgun/man is the head of the state/family according to neoConfucian doctrine, being this peculiar relationship between state/family practically unchanged until the end of World War II. The next brief list of important achievements in the emancipation of Japanese women throughout the twentieth century displays the contribution to the change of the image of women in the contemporary world:

1900: the first women's college was founded.

1911-1916: Hiratsuka Raichō ${ }^{-1}$ (平塚らいてう, 1886-1971) founded a literary organization called “Seitō sha” 青鞜社. She published a magazine, Seitō

\footnotetext{
${ }^{1}$ Mizoguchi Kenji (溝口健二, 1898-1956), author of eighty-five films (today only thirty-one are conserved), in Joyu Sumako no Koi (女優須 磨子の 恋, The Love of the Actress Sumako, 1947) and Waga Koi wa Moenu (わが恋は燃えぬ, My Love Burns, 1949) portrays Matsui Sumako (松井須磨 子, 1886-1919) and Kageyama Hideko (景山英子, 1865-1927), Japanese pioneers in feminism and advocacy respectively.
} 
青鞜, “Bluestocking”, in which only women could write. She stressed the liberation of women.

1920-1922: Hiratsuko Raichō and Ichikawa Fusae (市川房枝) founded Shin

fujin kyokai 新婦人協会 (The New Japan Women's Association,)

1946: Under the new Constitution, women's right was achieved. ${ }^{2}$

In modern times, social changes are also due to changes in the political landscape. The current family law was approved in 1948 after Japan's defeat in World War II. The law is based on basic human rights, human dignity, equality of sexes, and followed the footsteps of the Japanese Constitution promulgated in 1947. The main objective of this law was to reform the law of the Meiji Era family. Liberals demanded the abolition of $i e$, because they believed it was violating both human dignity and equality of the sexes, while conservatives were in favour of continuing ie. Finally, a law that insisted that the family should be a core consisting of parents and minor children was approved. Furthermore, it stated that family members could take any of two surnames, either the husband's or the wife's surname. Practically, however, the surname of the husband is generally the one that continues to be the name of a new family. (1948 Family Register Law 2015)

After the war, Japan quickly recovered its economic capacity, and thus household consumption increased significantly. Traditional shopping rushes of appliances occur. Husbands "get marred" with the company and work day and night, and meanwhile, the wives are behind doors again dedicating their time to raising children and being engaged in housework. Thus, with economic success, the division of labour is accentuated once again. Companies have replaced the ancient clans, employees thereof have replaced bushi, and Western suits have replaced traditional Japanese clothes. Fidelity to the clan has disappeared, and become the giri 義理 (“debt”) to the company. Labour reputation of the individual, important since the days of yore, has not lost its relevance today, and with it comes the concept of social death, which is a personal disgrace and therefore the entire company's problem, so it is avoided at all costs. (Pérez García-Valdecasas 2015)

Following the economic crisis caused by the rising of oil prices in 1973 and 1978 , the transformation of the manufacturing industry intensified. Women were

\footnotetext{
${ }^{2}$ During the Taishō era (大正, 1912-1925), in 1925 the Law of the right to vote to all adult male citizens is approved.
} 
leaving home more often. In fact, in 1975 one out of two women employees got married. Women were frequently hired as part-time workers. For the woman herself, her work complemented the family income, but in no case constituted a profession. She considered home the most important thing because there she had the authority and control over the money, including the husband's income. Working conditions and taxation did not favour the work of the housewife outside the home. On the other hand, the responsibility for the administration of the house fell on housewives, even when they had outside employment. In short, the economic prosperity of Japan was achieved in a relatively short time thanks to a sharp division of labour, with the total dedication of the man to paid work, fulfilling his social commitments to the job environment and subsequent absence from home. The marriage was seen as teamwork, with no equal male-female relationship. The husband-wife relationship was replaced by the mother-children relationship, because the mother was responsible for the upbringing and education of the children. (Briton 1993, 12)

In 1975, the International Women's Year was declared with the aim of improving the status of women. In 1979, The Convention on the Elimination of All Forms of Discrimination against Women (CEDAW) was issued by the United Nations General Assembly. Japan took time to ratify it. In doing so in 1985, Japan was committed to review both the legal system and customs. As a result, in 1985 the Equal Employment Opportunity Law (EEOL) was promulgated, and came into force the next year. As a conservative response to the law, working conditions for women worsened. In Japan today, there are still areas where the law does not apply, for example, in the area of traditional arts. Nonetheless, perhaps the reason is that the ancient arts, once their form was stabilized in an almost perfect condition, do not need the female presence at all, having survived without it during the passage of time.

In recent times, there have been other legal improvements such as the right to use the maiden name at work after marriage, the use of different surnames between the couple and the heritage that favors the wife. Because of the declining birth rate, in 1991 the Child-Care Leave Law to support working mothers was approved. (Introduction to the Revised Child Care 2015)

In 1999 the Basic Law on the Cooperative Participation of Men and Women in Society was enacted. Because of this law, equal participation in social activities by both sexes was promoted for the first time, and legal remedies were available to 
correct inequalities. The sixth article refers to the family, and states that both participants must carry all household activities equally. Moreover, despite all the legal changes affecting Japanese society, partly gained from feminist movements, partly promoted by some NGOs concerned with discrimination, the current situation is as follows: the birth rate has declined since the 1970s. The current average is 1.39 children per woman throughout her lifetime. A couple has on average no more than 2.2 children. The main causes are similar to those of other developed countries: the devaluation of wages, rising prices, increasing parental age, growth in the number of divorces, hedonism, dysfunctional family where the couple does not speak or have a relationship, the strengthening of the parent-child relationship and consequently their coexistence in the same household to a ripe age of the latter.

In short, Japan's traditional family has lost all value in the eyes of the modern population, and the image of women has evolved greatly, becoming almost opposite to the femininity of the Middle Ages, and with a certain access to political activities that was previously closed to women. From the 1980s families constituting one person have appeared. The family model is constantly evolving and hardly lends itself to a definition due to the increasing variety of forms and content. As for the present concept of femininity, certainly the delicacy, the sweetness, the gentleness, and the cuteness, especially for females below age 30, are on the top of the list. However, the gender role model had changed in such a manner that the current Japanese woman chooses her professional career again and again at the expense of her private life. Active, hardworking, independent and highly influenced by the Western feminine ideal perceived in films and other sources, the modern-day Japanese woman studies foreign languages, travels frequently and makes direct contact with Western culture, absorbing its ideas of the place of the woman in modern-day society.

Regarding the traditional theatre, however, the woman's place is still the same as in the past, being the labor reforms completely ignored. Meanwhile in Kabuki the onnagata was obliged to follow the rules established for the female members of Japanese society during the Edo period, ${ }^{3}$ while the woman in Noh theatre was

\footnotetext{
${ }^{3}$ Once the feminine presence had been banned by the bakufu, Kabuki theatre was in necessity to survive. One of the main points of the new Kabuki production was the appearance of the male interpreters responsible for the impersonation of the female characters. The term that defines this category of actors is onnagata 女形. In the past the onnagata were forced to carry the life
} 
simply completely absent. The idea of the female interpreter on the Noh stage is so outstanding even nowadays, that important magazines or newspapers will discuss it. ${ }^{4}$ The circumstance that the female interpreters are still not allowed on the Noh professional stage on a regular basis is due to the above-mentioned relationship between the tolerance and intolerance to a certain extent, though it can be also debated that the aesthetic significance of the transformation of masculine in feminine also plays an important role in preserving the conception of the traditional Noh production. Definitely, the main artistic and technique pattern, created by Zeami in his dissertations, is written by the male performer for the male interpreter's body and spirit. ${ }^{5}$ Even so, many of the Japanese traditional arts like tea ceremony or ikebana, initially introduced by the male master, with time have developed into arts shared by both men and women. In some cases, some of these arts have almost entirely become the female prerogative. Noh theatre has its own path, as Kyōgen, Bunraku and Kabuki do, with the gender-related licenses and prohibitions, and in the same manner these three kinds of dramatic art leave aside the female presence on the stage. Once the technique of female-character impersonation by the male interpreter was established, both actors and the conservative public have rejected the innovation/reintroduction of the female performer that could destroy - in their opinion - the ideal composition originated hundreds of years ago. In no case does it mean that female interpreters have never accessed the Noh stage. On the contrary, the feminine presence was quite

characteristic to the Japanese woman even offstage: dressing, sewing in their spare time, celebrating the women events, wearing makeup, varnishing nails with a special brush, blushing the cheeks with red, painting on top of the forehead a subtle eyebrows using a small brush, etc. Their voice changed slowly. Without becoming falsetto, it resembled the chirping bird. On the street the onnagata were a step behind the tachiyaku 立ち役 (“actor in Kabuki theatre playing the role of husband or lover"). This was integrated into the anti-naturalistic lines of Kabuki theatre. Unlike Noh actors, the onnagata from childhood were devoted to study the personality of a woman, her gestures, her nature, her manners, and charms just to impersonate her better than a real woman would reach it, and play a female character with greater refinement than any actress would do. The purpose was of becoming a woman, but a perfect traditional woman, seen through the eyes of man, a woman that exists only in the male imagination.

4 "Women in Noh", by Eric Prideaux, published in The Japan Times is a good example of it. The author states that the Noh stage is still dominated by the male performer, and explains the start of the modest access of the woman to the Noh stage as a hobby only in the early $20^{\text {th }}$ century. Nowadays, a very small number of female interpreters is admitted to the professional Noh stage, though they have to struggle with numerous prohibits because of their condition as women. The feminine discrimination in the Noh world is not referred only to the stage. The backstage is also still a male world, and their members such as costume designers, for example, mainly continue living in the feudal $i e$ in their private lives even today.

${ }^{5}$ In case of female interpreters, when they play male roles, they adjust their voices and their movements to achieve the highest resemblance to the man. 
important during the early days of Noh history. After the Noh world was established, with an absolutely masculine production environment, the woman took her position on the stage as a character only, once again manifesting the signs of classical Japanese femininity: passiveness, delicacy, submission, weakness, jealousy, ego, and sometimes obedience. Of course, it could be argued that the same characteristics can also appear in the masculine character in Noh, or even on the European stage, as universal human features. Nevertheless, those are always special features of an isolated character under certain conditions, and in no case can serve as gender characteristics regardless of socio-economic, educational, or religious conditions of its members, as it happened in traditional Japan to the feminine figure, conditioned by her image built and impersonated by man on the Noh stage during the last 600 years.

\section{Methods: Mask}

Regarding masculinity and femininity in Japanese society, several logical questions arise: How is the male performer able to reproduce traditional Japanese femininity on the Noh stage? What kinds of techniques are in his hands for the precise sex shifting on stage? Is it really feasible to convincingly convey the essence of the opposite sex during performance? Is it supportable to consider the naturalistic method of transmission of femininity by the male interpreter as the most suitable one? In fact, does the male interpreter transform into a female character realistically in the Noh play? Who, when and where is the transformation into a female character on the Noh stage, if at all? Wouldn't it be more appropriate to assume that the public observes only the outward signs adopted during the performance, that do not detract at all from the actor's masculinity? Perhaps there is absolutely no authentic change, but only a sample of external signs of the transformation.

Actually, femininity components, seen through the eyes of man, are successfully distributed in the total Noh mise-en-scène. Dance, mask, wig, and costume that are in use during the performance, the instrumental music produced by hayashi, the vocal music produced by jiutai and the interpreter, and the acting technique of the performer are responsible for the correct expression of the feminine character on the stage. All the above-enumerated constituents of the Noh performance draw attention to the simplicity as one of the main features of the Noh theatre. Simple props, masks, and tsukurimono 作り物 (“set pieces") 
emphasize the complexity of the costumes, the only constituent that stands out for its voluptuousness and majesty among other tangible items. Furthermore, these elements underline the message of the play. The mask, on the other hand, has a colossal supremacy in the whole mise-en-scène. Even the finishing of both the reverse and the front of the mask is significant. The back can smooth or obstruct the use of the mask, and therefore, can restrict the performance quality. Additionally, an inadequate resonance of the mask can collapse the interpretation, and hinder the advent of hana 花. Thereby, the mask can be considered one of the musical instruments in Noh, according to Udaka Michishige (2010, 104). With regard to the choice of the facial expression of the mask, it can add a completely new tone to the interpretation of the character. Beyond the costume, the wig, and the movements, the female mask with its delicate lines and round eyeholes ${ }^{6}$ intensifies the symbolic image of the character. Thus, the mask is not just a prop, but also a defining integrant of the performance with its great stage presence. The shite role performer chooses the mask in advance, months before the performance, according to his individual interpretation of the character (Udaka 2010, 34). The mask itself, a priori, has a neutral appearance as a heritage of the first Noh masks made originally by copying the faces of the dead. This notion is known as chükan hyojjo. ${ }^{7}$ It is considered as an essential component of the Noh performance, being one of the main characteristics of the Noh technique used by actors and all the Noh staff without mask, like musicians, chorus, and even kōken 後見. The so-called "neutral beauty" of the mask allows the actor to deliberately fill the stage with the sorrow or the joy that is dominating the character by using a different angle of the inclination of the mask. The elusiveness of the usually vaguely asymmetrical mask that is smaller than the interpreter's face itself, especially in case of the female mask, does not create any feature of the character, but evokes yūgen 幽玄 ("mysterious beauty"). ${ }^{8}$ The subtle and precise kata, the appropriately chosen fan,

\footnotetext{
${ }^{6}$ Masculine masks tend to have squarer eyehole. Actually, the shape of the eyes for both sexes reflects the natural body lines. As for female characters, these should have curves, while the masculine characters have more angles.

${ }^{7}$ Chükan hyōjō 中間表情 is an important aesthetic notion that encloses "an ambiguous expression neither definitively joyful nor sad" (Udaka 2010, 44).

${ }^{8}$ The complex concept of yügen, which literally means "the hidden and dark" and which originally was referred to the hidden meaning of sutras, is the most important term of the medieval aesthetics. Yügen can be understood as the highest form of harmonic and subtle spiritual beauty. Poetry, music, and singing "open the ears" of the public, meanwhile "the interpretation and dance" open their eyes. Therefore, the hidden beauty of the character will be manifested visibly, and will cause the audience a sense of empathy, or according to the terminology of Zen Buddhism, a kind of "enlightenment".
} 
and the stage costume and wig must complete the emotional picture of the main character. There is something else to consider when evaluating the mask. According to Udaka Michishige as regards, shite-kata and mask maker,

Noh's true uniqueness lies in the way it eschews any portrayal or visible reality, instead expressing the inner workings of the protagonist's heart and mind through a bare minimum of movements and chanting to aid the narrative progression, with musical accompaniment adding further dramatic color $(2010,146)$.

Although in this passage Udaka Michishige refers to the interpretative technique, it can be used when analyzing the mask in Noh. ${ }^{9}$ The "visible reality" of the Japanese, both nowadays and in the époque when the Noh theatre was established, has nothing in common with the mask's expression. The mask is just an idea that the actor should fill with emotions.

As is well known, Noh plays can be divided into five categories, and gobandate 五番だて (“the day's program”) is divided into five groups as well, both codified during Edo era (1603-1868):

a) shin 神 ("god")

b) nan 男 (“man”)

c) nyo 女 ("woman")

d) $k y \bar{o}$ 狂 (“madness")

e) $k i$ 鬼 (“demon”)

Each of these categories is called wakinoh-mono 脇能物, shura-mono 修羅物, kazura-mono 彭物, ${ }^{10}$ kurui-mono 狂物, or zatsunoh 雑能, respectively, and they are performed in this order. However, in modern Japan the usual Noh program consists of two Noh plays and Kyōgen in between. All the play categories have corresponding masks: onna 女 (“female masks”), otoko 男 (“male masks”), jo 尉

\footnotetext{
"Enlightenment" as a result of a long-term training process of Zen Buddhists was closely related to the similarly long-term training process that Zeami had drawn in his treatises. Nine levels of the actor's training, in other words "Way of Noh", were called to lead him to a supreme level of his art, that could be compared with the religious "enlightenment". (Reimer 1984, xxi)

${ }^{9}$ In should be noted that a number of plays do not make use of masks for shite character (hitamen mono 直面物 (“maskless pieces")), but only in case of male character.

${ }^{10}$ The number of the female masks increased rapidly thanks to the extension of the repertory in Zeami's times. They transmit all emotions characteristic to the medieval femininity image: from the classical quiet beauty of ko-omote to the highest expression of jealousy of the golden-eyed deigan.
} 
(“elderly characters' masks"), okina 翁 (“aged deities' masks"), ${ }^{11}$ kijin ${ }^{12}$ and kishin masks used for supernatural characters, and onryō 怨霊 (“spirits of the living or dead characters") masks. However, it is important to recall that in a number of Noh plays, divided into two parts, the main character suffers a dramatic transformation that involves a change of the costume and the mask. Mae-shite 前 シテ, the protagonist of the first half, is generally responsible for the introduction of some legendary character to the travelling waki ワキ ("supporting character in Noh performance"), while nochi-shite 後シテ habitually reveals the authentic personality of the main character during the second half of the performance that usually corresponds to the night dream of waki. The appearance of the main character is completely transformed at the kagami-no-ma, ${ }^{13}$ while ai-kyogen 相狂 言 ("folk character") relates the story of the first half of the performance in a simple and accessible language. In addition to the traditional ways of the mask change, there are those that endanger the health of the performer. Of course, in respect to the vision, regardless of the gender of the character, there is a longstanding technique in Noh to orient oneself using the pillars, but in the case of Dōjoji, the technique goes even further because of the actor's work with a very reduced vision that the mae-shite mask offers to him during the first half of the play, and the quick and dangerous change that follows. The timing of getting under the bell, which falls from the ceiling at the end of the first part of the performance, requires accurate calculation of the space and excellent physical condition of the performer. As the actor enters under the bell, a change of mask from one of the onna-men 女面 ("female masks used in Noh performance") to shinja ${ }^{14}$ costume, and wig, all of a female character, starts on the stage, unlike a usual mise-en-scène.

\footnotetext{
${ }^{11}$ The ancient ceremony of okina traditionally is designated to the pray for the longevity and a rich harvest. When Sarugaku was established, Okina was the opening play of the program, followed by several Noh plays.

${ }^{12}$ Kijin 鬼神 (demon), kishin 鬼神 (god). This kanji is characterized by a double reading. Depending on the context and pronunciation, the meaning of the term changes, signifying "kishin" a good god, meanwhile "kijin" meaning "an evil spirit".

${ }^{13}$ Kagami-no-ma 鏡の間 is a room with a large mirror separated from the stage by the colourful curtain. It is the space where the character is mainly created by the actor moments before the start of the performance.

${ }^{14}$ Shinja 真蛇, feminine ghost mask, characterized by jealousy and a desire for revenge. Used mainly by the nochi-shite in the second half of Dōjojji.
} 
Thus, as noted in the above examples, the mask is one of the stage components that emphasize the femininity of the character and communicates a wide range of emotions with the support of other stage elements. Nonetheless, it is not enough to only put on a mask in kagami-no-ma before arriving to the stage. Yet another factor confirms that the mask is not just part of the props. Unless the costume and wig are put on in the dressing room, the merging of the actor and character through the mask occurs in kagami-no-ma. Situated between the dressing room and the stage, the "mirror room", or sometimes called maku-no-ma 幕の間 (the "curtain room"), is a sacred space where shite sits down in front of the mirror, concentrates mentally and physically on the role, and finishes the creating of the character by putting on the mask and transforming into the protagonist. Udaka Michishige points out that "this is the moment when he pours all his emotions into the mask, and simultaneously, a sacred interlude in which the role he is about to play fills him (Udaka 2010, 127).

As already mentioned, a deep understanding of the role is absolutely vital. This understanding is required not only from the actor, but also from the mask maker. Both of them must be able to interpret the Noh story and the character's state of mind and be immersed in the character. Even a slight error of the mask maker can transmit a mistaken message to the audience.

\section{Stage Costume and Wig}

The angular silhouette of the costume, besides its aesthetic purpose, allows the actor to make the kata correctly, though the mask with its eyeholes cannot be adjusted exactly to the performer's eyes, and restricts the vision and the whole body control. Actually, the costume, the wig, and the mask are used with the purpose of overriding the actor's body, unexciting to the public in its individuality. The mask, for instance, serves to first negate the individual features and the language of the facial expression of the actor, with the complete annulation of the existence of the mask within the conciseness of the interpreter as the next step. The actor is annulled because of his main aim to serve as the mediator between the kami 神 ("gods") and the human beings, as it was the purpose of the original Noh performances in Kan'ami and Zeami times. However, currently Noh is not a religious experience anymore but a stage art based on an encounter between man and man. The costume, on the other hand, is denying the actor the individual features too, but calls the attention of the public in case of shite, whose robe is 
always bright in contrast with the dark and simple costume of waki, especially in plays of the third group. Being the central point of the character, the costume can symbolize many notions, for example, surihaku 摺管 (“white under robe") represents a woman's skin. On the other hand, iroiri 色入り (“presence of the red colour in the costume") can indicate the young age of the female character, while ironashi 色無し ("absence of the red colour") suggests that the heroine is not young anymore, though generally the costumes are just sophisticated versions of the medieval Japanese costumes.

According to P.G. O'Neill, all of the participants of the Noh play are responsible for the creation of the female character. Even musicians with their intricate melodies are creating the atmosphere characteristic of a play with a feminine protagonist (O'Neill 2001, 55). The creator of the stage costume, in this case, is a figure with exceptional importance. As it is known, the Noh-stage costume makers follow the rules of working in guilds. The organization of working in groups and the main terminology of this system, with the transmission of the skills from one generation to the next, is known in Japan since the appearance of the first Buddhist sects, and was adopted by Gagaku families within the arts around the beginning of the eighth century. P.G. O'Neill states that

These families specialized in the playing of one or other of the musical instruments used, or in the dancing; skills were passed on from one generation to the next or, in the case of especially secret techniques, from a father to one son only; no divergence from the traditional style of performance was allowed; and one family of Kyoto performers even had a monopoly of certain dances $(2001,16)$.

The cited transmission system does not differ from the one Zeami spread, or better put, used six centuries later, being its two main characteristics of the monopoly and secret transmission. ${ }^{15}$ This practice successfully demonstrates its vigor and longevity, having been used by the Sarugaku groups from the fourteenth century, and being applied to some extent even nowadays. Protection of the shrines and temples permits Sarugaku $z a$ 座 ("groups"), which enclose all of the interpreters, including musicians, and perform both Noh and Kyōgen in the province of

\footnotetext{
${ }^{15}$ The Gagaku monopoly system disappears "with the establishment of the Gagaku Bureau of the Imperial Household Ministry in the early years of the Meiji period, since when they have maintained no more than their particular associations with musical instruments or dancing" (O'Neill 2001, 16). As for the Noh world, the system continues being quite hermetic even nowadays with strict access selection of the new members from the families, traditionally linked to the Noh production.
} 
Yamato, to establish four lines that reach modern times: Kanze, Hōshō, Kongō, Konparu. Having the dramatic structure of Sarugaku Noh already completed with song, dance, and music in 1246, the actors though did not have the opportunity to regularly share stage experience, being dispersed throughout Japan. Therefore, they were forced to cultivate an individual performing style. Around the seventeenth century the four main Noh lines had disintegrated according to their professional specialization, creating new groups and schools with the hereditary succession to iemoto 家元 (“headship”), hiden 秘伝 (“secret transmission”) of traditional teaching, a permit system of becoming a professional member of the group, hierarchical organization, and "a strong sense of duty and obligation within a school" (O'Neill 2001, 18-20), and all those features currently in force.

The Noh costume maker families, like the Yamaguchi dynasty, vehemently preserve the ancient rules of costume production and the above-stated characteristics of the group routine. Even nowadays the main work of the costume production is the prerogative of the masculine master according to the ancient conception of the Japanese society gender division. Female family members may particpate in the production of fabrics or during dyeing process. However, there is no indication that the Equal Employment Opportunity Law (EEOL) works in this traditional sphere. Even admitted within production process, women frequently have access only to its lower echelons.

The present-day head of the Yamaguchi lineage, Yamaguchi Akira, is the founder of the Yamaguchi Noh Costume Research Center and the Azai Noh Gallery of Art in Shiga Prefecture, and son of the legendary Nishijin textile master Yamaguchi Yasujirō (1904-2010). The producing of the Noh costumes starts from the very beginning of the process - the planting of mulberry trees. After a number of steps on the way, Yamaguchi Akira chooses the correct colours of the future costumes, manufactures them and dedicates his time also to their maintenance. Besides that, the actual Yamaguchi master spreads the Noh-costume-production knowledge all over the world through lectures and participation in various Noh activities, reserving the right to tell the secret details of the fabricarion of the Noh costumes only to his heir, as the tradition requires. ${ }^{16}$

The scenic costumes in the ancient times were usually the property of the powerful patrons of the Noh groups. Until the Edo period the practice of throwing

\footnotetext{
${ }^{16}$ Interview with Yamaguchi Akira, Kyōtō, 7.8.2010.
} 
clothes on the stage was common. It was even customary to return the clothes the next day in exchange for a gift of money. During the Meiji Restoration (1868), the protectors like the Tokugawa administration had disappeared, following the head of the Kanze school and his patron, the last Tokugawa shoggun, upon his retirement in Shizuoka. The Noh schools had lost most of the stage costumes, which had been sold, in their struggle to survive in the changing world. However, some of these stage robes still belong to the Noh schools and are treated as treasures. The Yamaguchi master keeps those costumes in perfect condition not only to exhibit, but also for the continued use on stage. As for the relationship with the main client, the Noh actor, Yamaguchi Akira helps to choose the adequate costume for the next play during full of yugen meetings at his headquarters. The Noh tempo is the protagonist of such meetings, during which the actor and the costume master analyze the way in which the silk threads are carefully woven. Every single stitch, even being invisible from the stalls, composes the whole, and that whole must correspond to the picture the actor has in mind. Both the Noh interpreter and the costume master possess a deep knowledge of the play that is being prepared. The process does not finish once the actor choses the costume. On numerous occasions the costume master or his heir come to see the performance to determine whether the costume is really in harmony with the character the interpreter is creating. On the other hand, the actor through the costume and other stage elements must fulfill the following requirements: transmit the character's internal state of mind and evoke emotions in the public, which is guided to react emotionally, not intellectually to the Noh experience.

Regarding the wig importance, it is necessary to remember that the third group name is kazura-noh. Of course, male characters also use the wig in the other groups' plays, but only the woman pieces are denominated as "wig plays". The central figure of the play ${ }^{17}$ is dressed in a wig and a lavish robe, and is characterized by high lyrical quality, delicacy, yügen, and elegant dances. The place of the "wig pieces" corresponds to the second part, ha in jo-ha-kyu system, in other words, the development/climax part, and occupies the most important place in the whole Noh program according to Zeami (Inoura 1971, 123). However, some of the female characters are also within the fourth and fifth groups, and even in their madness or in the form of a fabulous animal amazes the viewers with the beauty of their costumes and wigs.

${ }^{17}$ All the analysis of the female character is referred to shite. Waki is always a male character. 
According to the character's age and status, there is a wide spectrum of wigs. Usually, they have long hair and are attached to a small piece of fabric and tied on the performer's head. The wigs specifically accompany corresponding masks. That is the case of white hair uba-katsura 姥髶 (“old woman's wig”) used for the aged Komachi character and accompanied by a $u b a$ mask. However, costumes, wigs and masks can be generally combined in many different ways and create a number of different characters.

\section{Techniques: Impersonation}

\section{Training}

The Noh actor usually starts to rehearse from a very young age. According to Zeami's theoretical works, the ideal age to start the Noh actor's career is seven, with the total freedom to perform the way the young interpreter wills. ${ }^{18}$ Nonetheless, nowadays different schools offer opportunities for younger age performers, bearing in mind that each age of the performer's career has its dramatic advantage. In each of the Noh schools, the young interpreter can choose to enter still preserves slight alterations in the text and both elements of physicalization — kamae and kata, ${ }^{19}$ full of inaudible and quiet tension-from one school to another. During the early training process, the young interpreter absorbs Noh texts and movements, gets familiar with the fan as the main object on the stage due to its multiple uses by the interpreter, and even tries to build tsukurimono. Moreover, the little actor learns to play Noh instruments and in some cases to make the masks.

\footnotetext{
${ }^{18}$ Zeami trusts the natural talent of the child at this age, starting to endure the training only little by little at the age of twelve. There are two next reasons for that: "Firstly, as he still has appearance of a child, whatever he does will have grace and subtle elegance. Secondly, his voice will carry well. Because of these two conditions, his weak points will be hidden, and his strong points will seem all the more splendid." (Zeami 2006, 64) At the age of seventeen, nevertheless, the young interpreter will loose his first hana, achieving the true hana only at the age of forty-five in case of assiduous work and tireless training.

${ }^{19} \mathrm{M}$. Bethe and K. Brazell do not distinguish between female and male kata in their study that concentrates on a different classification because of initial lack of such dissimilarity in the patterns. Both authors work with "the concept of ground (ji) and design (mon)" (Bethe and Brazell 1982, 3) rather than adopted by the Noh masters system of patterns with meaning and patterns without meaning. Their study reveals once again that there is no major difference in scenic patterns between male and female characters. The most important difference observed from their study is the one that refers to the speed and the width of the movement, and the energy used to make it.
} 
Training as a professional actor implies complete dedication to the ancient art, full of cross-gender experience and with no specialization. According to Kamei Yūji, shite from Hōshō school, a child born in the Noh family is not aware of any important event, no responsibility when he is brought for the first time to the Noh stage. He perceives all the elements that surround him as a game, especially dressing up in costumes of the past centuries. Once the performance is over, the young interpreter receives a lot of gifts and becomes the center of attention. Both serve as a stimulus for the further gradual introduction of the small actor on a professional stage. Little by little the individual rehearsals of the future shite or waki start and are held alone with the master who in some cases is the father of the young interpreter. Family and school secrets of the traditional art are passed down from generation to generation and are stored with the utmost reverence, avoiding abrupt changes or new interpretations, according to Kamei Yüji. Whether or not the young performer becomes a professional actor depends on himself. Will his hana bloom one day or not is a matter of his individual talent and dedication. Nobody will force him to learn the ancient technique. At the age of thirteen or fourteen a lot of kokata leave the Noh stage and associate their adulthood with other professions. Young interpreters who are loyal to the Noh stage make an effort both at school and at regular lessons with the Noh master. In the case of Kamei Yūji, who graduated from the Tokyo University of Dramatic Art, his learning was not limited to only the master's lessons. A turning point came when the actor had to go to live under the Noh theatre roof to penetrate the theatre spirit at a much higher degree than in the long years of training. However, the Noh system always leaves the performers ways to withdraw, though this only occurs at a certain point. Once defined and professionally consciously embarked on the Noh path, the actor has no choice but to perfect his art and cultivate hana.

The training includes some mandatory postures and movements that come from Zeami's treaties, or even from the medieval Buddhist statuary of the seventh century like an asymmetrical bent-knee position. This posture appears to be the perfect one for gathering energy and/or breath, with the focus in the lower abdomen, and is used in different activities as sports. The kuse 曲 ("static scene"), simple and easy to accomplish in the sight of an inexperienced foreigner, requires a great use of concentration and energy, achieving the actor's heartbeat of 180 beats per minute during this mute transmission of deep emotion. The absence of 
the visible movement increases the tension of expression of the character's state of mind even more. (Brandon 1997, 4)

The strict long exercise process of abstract kata and suriashi すり足 (“gliding walk"), that differ in the emotion, energy and texture from one Noh play to another, is of a physical nature. Also, it has a practical use, not only the visual expression of the character's feeling. As discussed above, the camp of vision is severely reduced by the mask. Therefore, the sliding walk helps the actor to control his energy and weight, though in case of a female role the actor has to keep the feet closer than for a male role, which makes it even more difficult to maintain balance. In addition to the mask, other obstacles such as a rigid costume, a very simple staging, or the permanently inclined torso position, make the actor concentrate on overcoming them with the use of the Noh interpretative technique characterized by a long-term learning and a great control developed during this period. However, the physicality of the training and of the performance itself, "based on the tension between opposites, which can be traced in part to the in-yo (yin-yang) concept of the harmony of dark-light, hard-soft, female-male", according to James R. Brandon, still does not guarantee the achievement of the hana to the actor $(1997,4)$. Udaka Michishige, who started his career at a very late age of twelve, indicates in his book The Secrets of Noh Masks that even a rehearsal does not provide the actor with the ability to get "inside the head of a character" using the established kata, simple in their shape and full of yuggen $(2010,7)$. After eleven years living at the house of his master, Kongō Iwao II, Udaka could start what the Westerners could call a freelance career. Actually, once the period of living under his master's roof ends, the young actor could only hone his craft on the stage of the same Kongō school. Having started a parallel career as a mask maker at the age of eighteen, he realized that he could create and express the character's emotion with the use of the mask, a sacred element on the stage from prehistoric times. ${ }^{20}$ Once and again, on the pages of his book, Udaka demands the actor capture the mental state of the character through a deep relationship with the mask that, due to its expression, determines all of the features of the character $(2010,28)$. The mask on the stage reveals the character by the correct use of the accent on the right side of the mask in the first half of the play and emphasizes the

\footnotetext{
${ }^{20}$ Labour reforms like the Equal Employment Opportunity Law (EEOL) did not impact the traditional flow of the mask creation by the male masters. The professional world of mask production remains closed to women.
} 
left side in the second. Udaka Michishige explains the secret of this use of the mask this way:

Because the shite in the first half is a wandering spirit unable to rest in peace, the right side features an eye that looks downturned, as if to express this state of limbo. In the second half of the play the character's soul is cleansed by the offering of a memorial service, resulting in a calmer countenance: a left eye gazes upward, a fuller cheek, and a corner of the mouth curved upward. (Udaka 2010, 154)

Adopted from Chinese dramatic pieces during the Nara period (710-794), the popular entertainment of Sangaku, lately known as Sarugaku-no Noh or simply Noh, with its dance, song, conjuring, music, acrobatics, and magic, successfully found its niche opposite the aristocratic genre of Gagaku, adding the national Japanese amusements to the original performance. Unlike the monopoly system known in later centuries, the new genre established gakuko 学子 ("official schools"), ${ }^{21}$ which were "set up to teach the various types of sarugaku and to provide players when required," states P.G. O'Neill $(2001,29)$. Correlated with gigaku and bugaku genres, later Noh inherited the gaku dance and jo-ha-kyz $\bar{u}$ 序破 急 ("introduction, development, climax") system of the play construction, intensified by Zeami and applied to the Noh mise-en-scène in the movement, voice and music performance. Once the new solemn entertainment of Noh had developed and had received protection from the temples, shrines and the ruling military class, the actors- usually coming from the low strata of society-adopted the $z a$ system with a hereditary headship, and were quite free during the year, except the special occasions in which they were expected to execute the duty performance. The absence could mean the cancellation of the protection. During the same time the Noh interpreters settled the mise-en-scène emphasizing singing, dancing, and monomane 物真似 “mimicry or imitating things"). Zeami argued that the imitation, though being performed with the use of highly symbolic movements, had to achieve such a state when the actor was completely identifying himself with the essence of the character and was not conscious anymore of his imitation of one of the three basic roles — old man, woman, or warrior — or a role

\footnotetext{
${ }^{21}$ The official schools of Sarugaku are abolished during the Heian period (794-1192), dividing the existing performers into two groups: the first one is attached to the Imperial Department of Music, and the second and the bigger one, consisting of the interpreters who became free and in necessity of some protection like the powerful temples or shrines. This division had driven the emergence of $z a$ with the monopoly of performance in the area of the temple or shrine to which they were attached.
} 
derived from those. ${ }^{22}$ The third group plays were indicated for the young shite who had to observe the ladies with every detail of their behavior and dressing to achieve the utmost detailed imitation. While "it should be a truly easy matter to perform the roles of simple ordinary women, since" the young performers were "used to seeing them every day" (Zeami 2006, 72), the access to the court ladies was restricted, and the shite performer had to contrive to research them. However, if the protagonist of the play was a noble lady or a simple countrywoman, the interpreter had to act the "general essence of a woman" (Zeami 2006, 72) in a "delicate, feminine manner". (Zeami 2006, 73) The third group plays were the most challenging for the male performers because of their physical condition, ${ }^{23}$ but also due to the necessity to imagine themselves involved in the female experience creating the

ultimate beauty in a state of kotan (refined simplicity), wabi (subdued elegance), and sabi (unadorned beauty), a kind of beauty going beyond the ethereal elegance of yuggen, which can be expressed by a flower blossoming on a withered bough. This is the essence of the symbolic beauty of Noh. (Komparu 1983, 15)

Another intangible element was the music.

\section{Music, Dance, and Song}

In the close-to-Noh performance genre of Kusemai, women in the male costumes, men and boys were accentuating the music at the expense of dance. Those interpreters were organized in groups dedicated to the independent Kusemai performance, disappearing from the capital area around 1430. However, Kan'ami, a Yūsaki-za 結崎座 actor of Yamato sarugaku, who had learned Kusemai from

\footnotetext{
${ }^{22}$ In other words, "the purpose is not a matter of thoughtful expression, but of emptying the mind of ego or self and taking on the true intent of the character being represented" (Zeami 2006, 17). Actually, Zeami insists in the imitation "something in its entirety" with "different nuances and degrees according to the situation" $(2006,71)$, However, he warns against too realistic imitation of the low things that in any case should be avoided "in front of members of the upper classes, who would find them ignoble and uninteresting" $(2006,72)$.

${ }^{23}$ While the usual Noh initial pose consists of the bent knees and the torso leaning forward, for the female character Zeami suggests to maintain straight knees, the pliant body, and to avoid excessive strength to hold the head. Also he pays much attention to the robe that should hide the man's body. The most important spot of his teaching about the female character impersonation is the appearance. "This being so, if you take care over your appearance, you should be able to portray womanly aspects well. No matter what sort of role you are playing, your appearance should never be poor; appearance is especially fundamental in woman's roles" (Zeami 2006, 73).
} 
1368 to 1374 from Otozuru, a female performer from Hyakuman school, ${ }^{24}$ had already included the Kusemai style of music into Sarugaku performance with emphasis on mimicry and certain refinement. ${ }^{25}$ Both musical styles-the ancient melodic Kouta 小歌, and the new dynamic Kusemai 曲舞—had merged promoting a new interpretative style. Moreover, the Kusemai texts became a great source for the Noh stories and quotations, and the Kusemai item itself became the main point of the Noh plays. Currently, dance sequences can be divided into hataraki 働き (“actions”) and mai-bataraki 舞働き (“dance actions”). Hataraki depicts the character with the use of portrayal actions and mimicry, corresponding to the iroe イロエ ("coloration") type with the elegant atmosphere of the female role. What is regarded as dance today, however, was in the original Noh a sequence of movements that were accompanying the kaiwa geki 会話劇 ("dialogue drama"). Actually, the primitive dialogue was not danced and was closer in its form to the medieval European drama than contemporary Noh. As for the female performers on the Noh and Kyōgen stage during the Muromachi period, their presence could not surprise anyone until the Edo period, when they were banned from the Kabuki stage, and therefore at the same time were excluded from other main performing arts.

Regarding the singing styles, on the other hand, two varieties can be observed:

a) Tsuyo-gin 剛吟 (“strong”) and a vivid style of the gods' and warriors' plays;

\footnotetext{
${ }^{24}$ Female performers were quite usual on the stage in this time. Miko Sarugaku Noh, at Kasuga Shrine, was expressly played by the virgins who were on service of shrines throughout the country. They were trained in Sarugaku Noh song and dance with the accompaniment of kotsuzumi 小鼓 ("small drum"), commonly used in the Noh play.

${ }^{25}$ Starting from Heian period the refinement was as must for the small-scale dialogues used as a punishment during the poetry contests at the Imperial Court. The loser was obliged to imitate the already existing plays of zae-no onoko, "plays of highly dramatic nature, with much dialogue, solid in structure, and rich in variety of content, particularly conflict", that could be considered as the prototypes of Noh, according to Inoura $(1971,47)$. Other genres like Dengaku with its supernatural inclination, songs, dance, and use of small drum and flute, Shugen Noh with its masks, drums, and flute, and ceremonial, ritual, comic or warrior's dances performed by priests of Shugendō, or Ennen Noh also could be considered as a preliminary model of the future Noh. The singers were in charge of singing the songs while the usually masked silent character was dancing in Shugen Noh. Dances, songs, and imitative acts with the further assimilation of masks and other dramatic arts characterized ritualistic banquet of Ennon Noh which usually was accompanying the Buddhist and Shintō ceremonies. Ennen Noh in the early years of the twelfth century, in Yamato Province, the subjects were quite close to the future Noh subjects, and were related to the historical tales of Japan, China, and India, avoiding the contemporary stories.
} 
b) Yowa-gin 弱吟 (“weak") and a melodic style conventional for the plays with the main female role, characterized by a more intricate scale system and melodic variety to express the emotion spectrum of the protagonist in the third and fourth groups of plays.

Besides, one of the important characteristics of the male impersonation of the female character in Noh consists of avoiding the imitation of the feminine voice. The male performers only sing in a higher key, differentiating in this point from the Kabuki interpreters. The actor and the jiutai generally perform the semichanting without any attempt of realistically reproducing the individual female character's voice.

The dance, on the other side, can transmit the character's sex through precise movements based on exquisiteness of form, especially seeking to transmit the portrayal characteristics in case of the female role. As a general rule, the third category plays, dedicated to the living or dead beautiful women or spirits of plants, involve the beauty of the texts and the quietness of the performer's execution. To accompany the slow tempo jo-no-mai 序の舞 (“dance widely used in the third category plays"), ${ }^{26}$ the drummers play a kotsuzumi, otsuzumi 大鼓 (“the side drum"), flute, ${ }^{27}$ and in some cases a taiko 太鼓 (“stick drum”), the biggest drum in the Noh orchestra (Goff 1991, 46). Other types of female dance can be performed according to the rank of the character. For example, chu-no-mai corresponds to an ordinary female character in the third group play. Besides, any female dance will transmit a sense of stillness and will be introduced with a different speed compared to the male characters'. With regard to the existence of the dance performed on the Noh stage by female characters in relationship with historical medieval Japanese society, Janet Goff in her study of the Japanese medieval literature mentions that these dances

could claim no such precedent in the Genji, where well-born women were expected to remain discreetly out of sight. [...] The presentation of most of

\footnotetext{
${ }^{26}$ Chü-no-mai 中の舞 dances have a strong presence in all Noh-play categories, and are characterized by a more quick tempo than jo-no-mai, though the instruments the orchestra plays in both cases are mainly the same.

${ }^{27}$ The flute is believed to be one of the elements that create the adequate bodily tension. The combination of the movement, or its absence, and the flute music create the quiet and controlled energy in the actor. Meanwhile, other visual elements could be adopted by the Western staging, the energy control observed in Noh appears due to a long-term training, and could not be easily implemented by the foreign performers.
} 
the women's plays as a dream, however, gives the female characters' dance in front of the waki a certain plausibility. (Goff 1991, 50)

Therefore, the dream on the Noh stage is used as a vehicle of artistic expression of an idealized alive or dead woman, deity, or spirit of plant, breaking up the historical veracity of the woman's day-to-day existence. As for the women's plays, besides the masks' and therefore plays' classification, kurai 位 (“the Tokugawa period ranking of plays") is also known and is still in use, recognizing the difficulty of the third group plays by giving to this category the highest rank.

It must be noted that the Noh performance is based on the central figure of the main character with an unchallenged position stated by Zeami. All other interpreters, stage components and koken are intended to support the interpretation of the protagonist, though the Western public would immediately notice the lack of the mandatory element in the West: dramatic lighting. Such a unique position of the main character allows him to wear the mask and to be the sole performer of the dance, accompanied by the singing of the jiutai, music, and words according to the school style standard. Since all members of the performance are working within the same style, the previous rehearsals roughly are not considered to be necessary. On the other hand, a small number of rehearsals, or the very first meeting of all the interpreters maintained in the dressing room just before going on stage, is observed due to the lack of time of the main role performers who are forced to teach instead of practice themselves because of economic necessity. Thus, there should be no place for the comparison of the quality of performance of ancient generations, concentrated only in the perfection of their art, with contemporary Noh, where it is not uncommon to detect mistakes in the text or the movement. Nevertheless, Noh as a living creature is constantly developing, and despite the strict training actors receive, there are no two identical impersonations, bringing every actor his own performing signature.

\section{Conclusion}

The laws like the Equal Employment Opportunity Law (EEOL) do not work at all in the area of traditional arts like Noh production. The mainly male Noh professional world does not allow the possibility of giving the opportunity of more active participation in the Noh production to the female participants. Thus, the Noh professional circle remains purely masculine despite the remarkable progress in other traditional arts. 
On the other hand, Noh, as a theatre of sublime tragedy, does not pursue the aim of introducing a story in a dramatic manner and avoids any sign of naturalism. Rather, it attempts to generate a mood to represent the character's inner state characterized by a spiritual beauty. Consequently, when the male interpreter transforms into a female character, it is more appropriate to consider his on-stage process as an attempt to abstract an intellectual approach to the female spirit, not to her physical image. This overlapping of the two genders happens on a rational level in a kind of arrangement between the audience and the masculine performer. The theatre of conscious convention exists since the time of Thespis' horse-drawn wagon, and is fully developed by theatre masters like Vsevolod Meyerhold (18741940). Most of the plays of the Spanish Golden Age are based on this concept, as does La Commedia dell'Arte or other types of popular theatre. Nevertheless, another traditional performing arts forms like Kabuki or the Beijing Opera pursue the complete metamorphosis of masculine to feminine through the use of the aesthetic procedures close to annulment of the own male nature thus approaching the earliest method of another Russian theatre master Konstantin Stanislavsky (1863-1938). Meanwhile, Noh performers break all illusion because neither voice nor suriashi or kata intend to deceive the audience. The stalls and the interpreters enter into a game without ever forgetting that this is a conscious deal between them, and that there is a masculine interpreter who represents a female character. This technique of conscious convention plays a much more important role in building the character, than a true and realistic reproduction of feminine gestures, way of walking, and voice pattern, while wig, mask and costume are present only to support the mentioned agreement. There is a constant fight against illusion, though it cannot be stated that this was the initial purpose of Zeami. Nevertheless, to modern eyes of the audience, familiar with the method of conscious convention, the unintended application of this technique is more than evident. The movements of the actor make the dispensable stage set and excessive characterization. Therefore, no obvious or realistic element will appear on stage, being replaced by delicacy and suggestion. And precisely for this reason, the female roles will be introduced without the male voice modification or a mincing walk. The male performer will use the same acting technique for all roles, but simply restraining while impersonating the female character. Only the mask and the costume that are already widely analyzed by numerous researchers will clearly indicate that the character is the female one. The construction of the right atmosphere follows the jo-ha-kyz principle, collected from the Indian musical tradition, used in Bugaku 
composition, and developed by Zeami in his papers. Though only two or three plays compound the current Noh program, they are presented in the order established by Zeami, starting the program with the god plays, and finishing with the devil plays. Actually, it is important to remember that before Zeami's arrival to the Noh stage, the main structure of the play and the program itself were already established by the preceding Sarugaku Noh performers. His great merit consists of polishing the texts, creating the production mode and supporting the interpreter's work with the treatises. ${ }^{28}$

The mask is used as the central point of the play. Through its use the shite creates the right emotional atmosphere on the stage and in the stalls without trying to play femininity. To achieve this purpose, the performer chooses the mask carefully among analogous masks considering that the same one can be used in different plays to depict similar characters. In case the protagonist does not use the mask on the stage, even then he maintains the intermediate expression of his face just as the rest of the interpreters. The mask is even considered to be a live element in the polytheistic Japanese tradition, with its own nature the actor is called to portray. The performer merges with the spirit of his role while he is observing his masked reflection in the mirror at kagami-no-ma before the performance starts, with the purpose of becoming one with the mask.

The male performer is in charge of expressing the character's inner state in a very complex way. The Noh conception allows him to do it on three different levels: interpreter, woman, and in the case of Izutsu play even the male ghost that represents the spirit of the dead husband who possesses the woman (Brandon 1997, 202). In simpler plays the male performer's task has fewer levels, though they are not plain at all: the male performer transforms into a woman.

\footnotetext{
${ }^{28}$ Inoura $(1971,85)$ suggests the following Noh development analysis: the period of consolidation, the period of change, and the period of stabilization. The first period could be divided into three phases: a) 1351-1384; Kanze Kan'ami Kiyotsugu; theories of yügen and monomane; transition from Sarugaku Noh to Nohgaku; b) 1384-1443; Kanze Zeami Motokiyo; treaties of Noh principles; importance to song and dance; nyotai onna-mai 女体女舞(“dances in form of women”), c) last years of Zeami-1470; Kanze Onnami (1398-1467) and Konparu Zenchiku (1405-1468?); brilliant Noh style by Onnami, and metaphysical Noh by Zenchiku; establishment of the Noh program: Okina ceremony, three Noh plays with Kyōgen plays in between; development of Nyōbō Sarugaku performing the women the roles composed for male interpreters. The latter two periods reflect numerous changes in the Noh development after Zenchiku's death.
} 
The widely known aesthetic concept of $y \bar{u} g e n,{ }^{29}$ character development, and the understanding of the message of the play are achieved through bodily practice. Thus, the actors do not analyze the aesthetic or physicalization of their art, avoiding any unnecessary verbalization in Noh theatre. The theoretical and/or intellectual understanding of yūgen itself, ${ }^{30}$ widely developed by Komparu Zenchiku in his essays, in no case can be considered the main purpose of the Noh performers engaged in practical use of both aesthetic and physicalization. The Noh technique of building a character is in confrontation with one of the most important performing techniques in the West, the Stanislavsky method. Though the Russian director and dramaturgist suggests the interpreters to create the character's internal life with a deep analysis of their own interior world, Zeami chooses an opposite procedure. He encourages the performers to look around and to "(learn techniques of dance and song), then bring that experience inside (apply song and dance to the character), and finally express it outwardly again (perform the internal essence of the character with yügen)" (Brandon 1997, 9). Nowadays, $y \bar{u} g e n$ is both part of non-intellectual knowledge of Noh and the trained Japanese audience accustomed to the nonverbal communication on the stage. Regarding the public proficiency during Edo period, due to the limited Noh repertoire and numerous established rules, the audience could achieve the same level of understanding Noh as the performers. As a result, once this relationship between the two groups of connoisseurs was established, the onstage team stopped to consider the explanation of the difficult points of the play to the observing team, maintaining this tradition even nowadays. However, the gap between both factions of members of the performance had increased with the fall of the shogunate regime. The understanding of the non-realistic Noh performance and the acceptance of the ancient performing art as a route towards "enlightenment" had become a forbidden land for the greater part of the contemporary Japanese

\footnotetext{
${ }^{29}$ Borrowed from China, where it was strongly connected to the Buddhism, the concept of yügen has greatly influenced classical Japanese culture. There may be mentioned the aesthetic quality in waka and renga, as an example, both of them paving the way for the creation of the atmosphere on the Noh stage. Nevertheless, Noh yügen rejects the pure or "raw" beauty, and pursues the hidden, deep, and elevated one as an expression of the highest art. It is considered to have reached its greatest splendor during the early years of Muromachi period. (Nose 1981, 202-4, 286)

${ }^{30}$ Two theatre men, Zeami and Zenchiku defend contrary views on the yūgen perspective. "Whereas Zeami had defined yugen in terms of stage effect- that is, from the perspective of the audienceZenchiku looks upon yügen as a mental realm of the performer" (Brandon 1997, 45). Both define the way the actor develops a character. Yügen by Zeami was mostly referred to the chant and dance, and was specific for any acting technique of every group of the plays with the purpose to make even an ugly character beautiful.
} 
audience, particularly very young one, mostly unfamiliar with the medieval suggestion, subtle and profound style, high spirit, and deep meaning of the action full of insinuation and conventions. ${ }^{31}$ On the other hand, foreign public especially lacks the tools to understand the hidden meaning of Yügen during Noh theatre touring abroad. Nevertheless, even at present, the instructed and prepared audiences still can participate in the ceremony unfolded before their eyes, which especially impacts with the art of the interpreters and its great dramatic tension.

\section{References}

“1948 Family Register Law.” 2015. Accessed February 26, 2015. http://members.jcom. home.ne.jp/yosha/yr/nationality/Family_register_law_1948.html.

“Algunos Shite típicos desde deidades hasta demonios.” Accessed June 13, 2014. http://www.japonartesescenicas.org/teatro/generos/noh/simbologia6-4.html.

Bethe, Monica, and Karen Brazell. 1982. Dance in the No Theatre. Vol. 1-3. Cornell University East Asia papers, New York: Ithaka.

Brandon, James R., ed. 1997. Nō and Kyōgen in the Contemporary World. Honolulu: University of Hawai'i Press.

Brinton, Mary C. 1993. Women and the Economic Miracle: Gender and Work in Postwar Japan. Berkeley and Los Angeles: University of California Press.

Goff, Janet. 1991. Noh Drama and The Tale of Genji. The Art of Allusion in Fifteen Classical Plays. Princeton Library of Asian Translations, Princeton: Princeton University Press.

Hofstede, Geert. 1980. Culture's Consequences: International Differences in WorkRelated Values. Beverly Hills CA: Sage Publications.

Inoura, Yoshinobu. 1971. A History of Japanese Theater I. Noh and Kyōgen. Yokohama: Kokusai Bunka Shinkōkai (Japan Cultural Society).

Komparu, Kunio. 1983. The Noh Theater. Principles and Perspectives. New York/Tokyo: John Weatherhill, Inc.

Nose, Asaji 能勢朝次. 1981. Yūgenron (幽玄論) (A Theory of Yūgen), Vol.2. 中世文学 研究. Medievel Literature Research. Kyoto: Shinbunkaku Shuppan.

\footnotetext{
${ }^{31}$ According to Nose, Zeami considers the skill to comprehend yūgen as a natural feature of the Japanese national character, being the public able to distinguish between the vile beauty and the beauty full of yügen, that in case of women role should be similar to the ideal beauty of the Heian period noble ladies, in nosakushō 能作書 (Nose 1981, 327, 330). Furthermore, Zeami stresses that

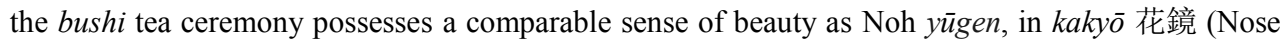
1981, 327, 330). On the other hand, yügen should be invisible, but strong enough as to dominate the whole mise-en-scène, and the voice, suriashi, movements, and other elements building a character (Nose 1981, 331).
} 
O'Neill, P.G. 2001. "Collected Writings of P.G. O'Neill." In The Collected Writings of Modern Western Scholars on Japan, Vol. 4. Edition Synapse. Tokyo: Japan Library.

Pérez García-Valdecasas, Joaquín. 2010. "El milagro japonés. Eumed.net." Observatorio Iberoamericano de la Economía y la Sociedad del Japón 2 (7) (enero). Accessed February 26, 2015. http://www.eumed.net/rev/japon/07/jpgv.htm.

Personal interview with Kamei Yūji (Hōshō school), Tokyo, 2012.

Personal presence of the author during the meetings of Mikawa Izumi and Imai Yasuo, both from Hōshō school, with Yamaguchi Akira, Kyoto, 2010.

Personal interview with Yamaguchi Akira, Kyoto, 7.8.2010.

Prideaux, Eric. Apr.11, 2004. “Women in Noh.” Accessed March 4, 2015. http://www.japantimes.co.jp/life/2004/04/11/to-be-sorted/women-in-noh/\#.VPbEBh Z2dFI.

Reimer, J.Thomas. 1984. On the Art of the Nō Drama. The Major Treatises of Zeami, translated by J.Thomas Reimer and Masakazu Yamazaki. Princeton Library of Asian Translations, Princeton: Princeton University Press.

Udaka, Michishige. 2010. The Secrets of Noh Masks. Tokyo, New York, London: Kodansha International.

Zeami. 2006. The Flowering Spirit (Füshikaden). Classic Teaching on the Art of Nō, translated by William Scott Wilson. Tokyo, New York, London: Kodansha International. 